\title{
Transport development as a factor in the economic security of regions and cities
}

\author{
Vladimir Plotnikov ${ }^{1,2, *}$, Ivan Makarov ${ }^{3}$, Irina Shamrina ${ }^{3}$, and Olga Shirokova ${ }^{3}$ \\ ${ }^{1}$ Saint-Petersburg State University of Economics, 21 Sadovaya str., St. Petersburg, Russia, 191023 \\ ${ }^{2}$ South West State University, 9450 let Oktiabria str., Kursk, Russia, 305040 \\ ${ }^{3}$ Financial University (Lipetsk branch), 12 Internacionalnaya str., Lipetsk, Russia, 398050
}

\begin{abstract}
Object of study - the impact of the transport system on economic security. Applied research and calculations are performed on the example of the Lipetsk region (Russia). The study used methods of system analysis, performance evaluation, statistical method, calculation of Engel and Uspensky coefficients, etc. Analysis of data on the provision of transport infrastructure in the regions of Russia and other countries showed that insufficient development of transport is a "weak spot" in Russian regions. To solve it, the following measures were proposed: development of public urban transport, modernization of the integrated transport system of urban agglomerations, introduction of a strategic approach to managing transport development, construction of toll roads and highways, more active use of electronic control systems for urban transport systems. To assess the effectiveness of the development strategy of urban transport systems, the authors suggested using a number of criteria. This is a criterion of fiscal efficiency; environmental performance criterion; criterion of strategic coherence. Their use allows optimizing the development of transport in Russian cities. As a result, the economic security of their development will be reliably ensured.
\end{abstract}

\section{Introduction}

The modern economy is characterized by the growth of connectedness of the economic space [1-3]. The intensity of traffic flows is constantly growing. Therefore, an urgent task is to increase the efficiency of using transport opportunities at the territorial level (in regions and cities). Especially important is the effective solution of this problem for Russia [4]. In many regions and cities of the country, the situation with the state of the transport infrastructure has a significant impact on the parameters of economic security and sustainable development. Moreover, the problem of the low development of transport infrastructure is traditional, which found expression in national humor. "Russia has two misfortunes - fools and roads." This phrase is attributed to various historical personalities (writers, historians, statesmen, etc.); it is quite popular.

Insufficient development of the transport infrastructure in Russia is determined, first of all, by geographical factors. Russia is the largest country in the world, with the most part of

\footnotetext{
*Corresponding author: plotnikov_2000@mail.ru
} 
its territory having unfavorable climatic conditions. This leads to a low population density and a low level of economic development of large areas. A dense road network in these conditions is not always necessary. In addition, there are not enough resources to create and maintain it.

On the other hand, as is known from system analysis, sustainability, economic security of a socio-economic system is determined by its integrity and coherence. The system principle of the "weak element" states that the reliability of any system is determined by the reliability of the weakest of its elements (subsystems). Such a "weak element" for the Russian regions and cities is the transport infrastructure. For the socio-economic system of a region, urban agglomeration or city, the most important element is the transport system that ensures their daily activities. Transport is important for all spheres of production and service, social and economic activity of households.

Insufficient development of transport in the region, agglomeration, city is a threat to economic security. The purpose of the article is to study transport as a factor in the economic security of regions and cities.

\section{The role of transport in the economy: a general view}

If we consider the whole range of problems related to the transport provision of the territories, we can single out priority ones among them. The most important problems, according to the authors, are the following: (1) the organization of road traffic of urban public and private transport in major cities and metropolitan areas; (2) the organization of effective interaction of urban and regional transport systems in the transport provision of urban agglomerations. The solution of these problems is connected with the level of development of the network transport infrastructure.

Assessing the impact of transport on the dynamics of socio-economic systems, the Nobel Prize winner in 1974, Friedrich August von Hayek (1899-1992) in the first half of the 20th century, advanced the thesis that a quantitative increase in the available stock of physical means of subsistence and life convenience depends not visible transformation of one substance to another, how much from the process of their movement. Thanks to this movement, the relative importance and value of goods changes. Hayek was an adept market economy. He believed that human needs are most fully met as a result of market barter. At the same time, transport creates the possibility of market exchange, and the market, in turn, stimulates the development of transport. That is, the development of the economy (and ensuring economic security) and the development of transport are interdependent processes.

As shown by the results of previous studies [5, 6, 7, and other], a developed transport system contributes to: an increase in the level of production and consumption; lower market prices; reducing the differentiation of economic and cultural levels of the regions; the rapid spread and introduction of new technologies; the growth of labor mobility, including the influx of labor in economically developed areas; etc. In general, the development of transport has a multiplicative effect on economic systems, contributes to an increase in public welfare, and therefore increases economic security.

\section{Methods for assessing the development of transport infrastructure in the region}

The level of development of transport affects economic development. A developed transport system increases comfort for the population, as well as reduces the costs of doing business. In addition, the development and selection of investment projects takes into 
account the degree of development of the region's infrastructure, primarily the transport complex. Therefore, there is a need to assess the transport infrastructure of the region.

In assessing the level of socio-economic development of a region, the Engel and Uspensky coefficients are usually used to characterize the level of transport provision:

- German economist and statistician Ernst Engel (1821-1896) proposed a formula for assessing the transport security of a territory $E$. The calculation is based on the length of the transport network, correlated with the developed territory and the population of the region:

$$
E=\sqrt{\frac{l}{S} \cdot \frac{l}{N}}=\frac{l}{\sqrt{S \cdot N}},
$$

where $l$ is the length of the transport network, $\mathrm{km} ; S$ is the area of the developed territory, thousand $\mathrm{km}^{2} ; N$ is the total population, thousands of people.

- This formula was modified by the Russian scientist Yuri Uspensky (1873-1929) by introducing an additional indicator under the radical sign that characterizes the volume of cargo traffic. This indicator $U$ is calculated by the formula:

$$
U=\sqrt[3]{\frac{l}{S} \cdot \frac{l}{N} \cdot \frac{l}{M}}=\frac{l}{\sqrt[3]{S \cdot N \cdot M}},
$$

where $l$ is the length of the transport network, $\mathrm{km} ; S$ is the area of the developed territory, thousand $\mathrm{km}^{2} ; N$ is the total population, thousands of people; $M$ is the total mass of goods presented for transportation, thousand tons.

Unlike the Engel formula, the Uspensky formula takes into account the relationship between the general level of development of the regional economic system and the length of the transport network. Initially, the Uspensky and Engel formulas were derived to assess the level of provision of the region with a network of rail transport. At present, the general level of transport provision of the territory, both by rail and by road, is calculated by the formula (2), while the length of the road network is multiplied by a correction factor of 0.15 (for highways 0.45).

The Table 1 shows the indicators of the development of transport infrastructure of the Lipetsk region of the Russian Federation, the macro-region - the Central Federal District (CFD) of the Russian Federation, as a whole Russia.

Table 1. The level of development of transport networks of various territories (Compiled by authors).

\begin{tabular}{|l|c|c|c|c|c|}
\hline \multicolumn{1}{|c|}{ Indicator } & $\begin{array}{c}\text { Lipetsk } \\
\text { region }\end{array}$ & $\begin{array}{c}\text { Central } \\
\text { Federal }\end{array}$ & Russia & France & USA \\
\hline Population, thousand people & 1215.2 & 36482.0 & 143954.0 & 60180.5 & 290343.0 \\
\hline Territory, thousand km² & 24.1 & 652.8 & 17075.4 & 547.0 & 9363.0 \\
\hline Total length of roads, thousand km & 5.4 & 104.4 & 763.0 & 902.7 & 3900.0 \\
\hline including highways, thousand km & no data & no data & no data & 9.9 & 89.4 \\
\hline Density of roads per 1000 km², km & 220.7 & 160.0 & 44.7 & 1650.3 & 416.5 \\
\hline Engel coefficient (roads) & 31.1 & 21.4 & 15.4 & 157.3 & 74.8 \\
\hline Uspensky coefficient (roads) & 11.7 & no data & 3.1 & 55.0 & 18.2 \\
\hline
\end{tabular}




\begin{tabular}{|l|c|c|c|c|c|}
\hline $\begin{array}{l}\text { Total length of the railway network, } \\
\text { thousand km }\end{array}$ & 0.7 & 17.4 & 86.0 & 31.0 & 159.9 \\
\hline $\begin{array}{l}\text { Density of the railway network per } \\
1000 \mathrm{~km}^{2}, \mathrm{~km}\end{array}$ & 29.0 & 26.6 & 5.0 & 56.7 & 17.1 \\
\hline Engel coefficient (railways) & 4.1 & 3.6 & 1.7 & 5.4 & 3.1 \\
\hline Uspensky coefficient (railways) & 0.9 & 1.1 & 0.6 & 1.9 & 1.0 \\
\hline $\begin{array}{l}\text { Sending goods by road, thousand } \\
\text { tons }\end{array}$ & 3196 & no data & 6125000 & 134408 & 3633000 \\
\hline $\begin{array}{l}\text { Sending goods by rail, thousand } \\
\text { tons }\end{array}$ & 15000 & 187000 & 1058000 & 126800 & 1557000 \\
\hline $\begin{array}{l}\text { Cargo density of the railway } \\
\text { network, tons / km }\end{array}$ & 21429 & 10747 & 12302 & 4090 & 9737 \\
\hline General transport provision & 3.1 & no data & 1.1 & 10.4 & 3.8 \\
\hline
\end{tabular}

The data are presented in comparison with France and the USA (data are relevant at the beginning of the 21 st century, collected by authors from various official statistical sources).

The table shows that the density of roads and railways in the Lipetsk region is $1000 \mathrm{~km}^{2}$ more than the average for the CFD and significantly exceeds the average for Russia. Lipetsk region is in fifth place among the regions of the CFD and the seventh in Russia in terms of the density of the railway network. It is also on the 7th place in the density of highways. Here it is interesting to note that according to the official assessment of the Ministry of Economic Development and Trade of the Russian Federation, in terms of socioeconomic development, the Lipetsk region is also among the top 10 most economically developed regions of Russia (excluding autonomous districts). However, if we take the Engel coefficient as an indicator of the level of development of the road network, the results are different. The rank of the Lipetsk region is decreasing. Nevertheless, the Lipetsk region falls into the 20 regions with the highest level of development (in terms of the density of roads, taking into account the population - 19th place).

If the situation in Russia is used as a base for comparison, the indicators of the Lipetsk region are at a high level. Comparing the indicators of the level of development of the network transport infrastructure of the regions of the Central Federal District, in particular, the Lipetsk region, with similar indicators of the United States or France (the characteristics of the transport system of France largely coincide with the average European indicators), we can see that only the density per $1000 \mathrm{~km}^{2}$ of the road network is inferior to the American more than twice, and French more than five times. This should take into account the difference in the quality of roads, as well as the fact that more than $60 \%$ of the road surface does not meet technical standards.

From the above data we can conclude that if the transport policy in Russia is not changed, then the road network will soon become not only a brake on socio-economic development, but also a threat to economic security. The increase in the number of motor vehicles in conjunction with the aging of the road network leads to an increase in the number of road accidents, property damage, death and injury to people. During 2017 in Russia, there were 169 thousand traffic accidents, in which 19 thousand people died and more than 215 thousand were injured [8].

The situation with the development of railway transport in the Lipetsk region is more optimistic. The density of the rail network in the Central Federal District and the Lipetsk region exceeds that in the United States and is slightly less than the European average. At the same time, a significant part of freight traffic is carried out by means of railway 
transport. The cargo density of the railway network significantly exceeds the indicators of the considered countries of the world. This can lead to an increase in the network wear rate and, as a result, to a decrease in the speed of delivery and an increase in transport risks.

\section{Features of the development of transport in Russian cities}

The level of development of transport affects economic development. A developed transport system increases comfort for the population, as well as reduces the costs of doing business. In addition, the development and selection of investment projects takes into account the degree of development of the region's infrastructure, primarily the transport complex. Therefore, there is a need to assess the transport infrastructure of the region.

The socio-economic development of the city is accompanied by an increase in the level of citizens' well-being [9]. The growth of wealth, in turn, causes the growth of motorization. In addition, an important consequence of economic growth in the city is an increase in land prices and an increase in the density of buildings. As a result, the major cities of Russia, while maintaining the growth trend of motorization of the population, in conditions of exhaustion of the possibilities of extensive development of the transport network due to the lack of free land in cities, in the near future will urgently need to form and implement a new strategy and technology for the development of urban transport systems. The purpose of such strategies is to ensure the transport accessibility of the city as a whole and its individual parts.

At the present stage of development of cities in Russia, as the main problem of the functioning of their transport space, we highlight the need to improve the efficiency and intensity of use of the existing transport infrastructure. The mode of use of this infrastructure should be optimized. The optimal use of the agglomeration transport space implies the maximization of the use of all the available spatial and territorial resources of the transport system, taking into account the priority development of the most efficient (for a given agglomeration or city) modes of transport. In particular, in Russian cities, special attention should be paid to the development of a high-speed tram, a "light" metro and other new types of passenger transport.

At the same time, the development of transport should cover not only the territory of the city, but also the entire agglomeration. Transport links should be built between its elements (settlements) with the maximum use of railway transport and other available infrastructure. Moscow is a good example. The Moscow Ring Railway was formed in this large city, which has become an integral element of urban transport [10].

To assess the strategies for the development of transport in cities, we propose to use a number of criteria:

- The criterion of fiscal efficiency. According to this criterion, the functioning of the city's transport system must be subordinated to the principles of minimizing budget expenditures and maximizing profits (minimizing losses).

- The criterion for environmental performance. This criterion is associated with sustainable development. The functioning of the transport system of the city should bring minimal damage to the natural environment (habitat of residents) [11].

- The criterion for strategic coherence. It implies the harmonization of goals and measures for the strategic development of the city's transport system and the development strategy of the city and the region itself. This criterion implies the need to form a unified concept and, in the future, a strategy for the development of urban agglomeration, a synthesizing strategy for the development of settlements in the agglomeration, and a transport strategy for agglomeration and its constituent elements, correlated with the general strategy for the development of agglomeration.

The optimal transport strategy during its implementation should provide: 
- Reduction of the cost of transportation of freight carriers and temporary losses on the transport activities of city residents.

- Improving transport accessibility of the city and / or agglomeration areas.

- Reducing accidents in the city's transport system and / or agglomeration.

- Optimization of the use of the land fund, on which the transport space of the city or urban agglomeration is located.

One of the promising areas for the development of transport infrastructure in Russia, in our opinion, is the construction of toll roads and highways in large cities and metropolitan areas. The success of this direction of development is confirmed by the experience of construction and operation in St. Petersburg of the Western High-Speed Diameter [12]. Urban highways in Japan and Australia can also serve as an example of the introduction of such transport systems.

The implementation of our proposal should be consistent with the urban and regional transport strategy. It is necessary to form a graph of the existing transport system. Then - to analyze and establish: to what extent the introduction of toll roads will solve the problem of optimizing the transport accessibility of urban areas. One of the main problems of the implementation of the toll road system is the problem of the construction of checkpoints separating public highways from the toll section of transport routes.

Under conditions of dense urban development and lack of land acquisition, this situation, if solved within the framework of traditional approaches, could indeed become a problem. Recently, however, there has been a rapid development of information technology [13]. This makes it possible to solve the problem under consideration by installing on the roads fixtures for cars entering the toll section of the motorway, or leaving it.

With the development of transport systems in cities, the problem of end-to-end traffic management becomes acute. This system should provide effective interaction of traffic light systems (especially the traffic light systems of urban highways and adjacent roads, major interchanges, as well as multimodal interaction). The main thing in the functioning of such systems is the presence and constant provision of dynamic feedback for the functioning of the system elements with a change in the traffic flow parameters and the time of day. The introduction of such systems is of particular interest in combination with the idea of introducing urban toll roads.

The widespread introduction of information technology in the system of organization and traffic management allows translating into reality variable rates, depending on the route of the vehicle. This can be achieved both through the use of video cameras installed on tollfree and main free highways of the city or agglomeration, as well as through the equipment of checkpoints or junction points of toll-free roads and cars with special electronic devices that allow you to track the route and make calculations automatically.

The question of effectively functioning "capillary" roads, functionally coordinated with the main urban highways, remains topical - without their availability, the efficiency of the urban transport network will be low. It is necessary to take into account that in the modern city the toll road system should function in combination with the possibility of transferring people to public transport. At the same time, the lines of urban public transport can be financed, along with budget financing, through the flow of income from the functioning of paid infrastructure facilities (roads and parking lots).

\section{Conclusion}

The level of development of transport infrastructure is a factor that strongly influences the economic growth, quality and standard of living of the population, economic security. Particularly acute problems of transport development are in cities and urban agglomerations, where there is a high population density and high intensity of economic 
activity. Failures in transportation can have a negative impact on welfare and sustainability of development. The growth of motorization of the population, the opening of new industrial enterprises and the reconstruction of existing industries require the expansion and reconstruction of the transport infrastructure of most Russian cities. The transport complex, as well as the entire economic system of the city, the agglomeration and the region is not an isolated system, therefore the issue of transport security should be addressed within the framework of a strategic approach. In this case, special attention should be paid to the development of new types of transport (including toll roads), as well as the use of modern information management systems for its operation.

\section{Acknowledgements}

The paper is an output of the science project of the government task of Ministry of education and science of the Russian Federation \# 26.3546.2017/PCH "Development fundamentals of analysis and prediction of structural and dynamic parameters of the regional economy are based on the integration of the Russian and world experience of management of territorial development and modern scientific doctrines".

\section{References}

1. H.M. Abdo, Mondes en Developpement 176(4), 137-152 (2016).

2. M.O. Ambrosetti, Rivista Geografica Italiana 89(2), 395-402 (1982).

3. Y. Vertakova, Proc. of the 27th Int. Business Information Management Association Conf. - Innovation Management and Education Excellence Vision 2020: From Regional Development Sustainability to Global Economic Growth, IBIMA 2016, 11001108 (2016)

4. I. Makarov, V. Plotnikov, MATEC Web of Conferences 170, 05012 (2018) doi: 10.1051/matecconf/201817005012.

5. G. Abrate, M. Piacenza, D. Vannoni, Regional Science and Urban Economics 39(2), 120-127 (2009)

6. D.A. Macheret, Economics of Railways 10, 16-29 (2003)

7. M. Rifkat, A. Roza, S. Leonid, D. Renat, 20th ITS World Congress Tokyo (2013)

8. URL: http://www.1 gai.ru/autonews/520130-gibdd-opublikovala-godovuyu-statistikudtp-za-2017-god.html

9. U.G. Benna, Industrial and Urban Growth Policies at the Sub-National, National, and Global Levels (IGI Global, Hershey, PA, 2019)

10. URL: http://mkmzd.ru/ring

11. Y. Vertakova, V. Plotnikov, Economic Annals-XXI 166(7-8), 4-10 (2017) doi: 10.21003/ea.V166-01

12. URL: https://nch-spb.com/o-proekte

13. Y. Vertakova, V. Plotnikov, Economic Annals-XXI 156(1-2), 37-40 (2016) doi: 10.21003/ea.V156-0008 